\title{
INTERACTION OF TROPONIN C AND CALMODULIN WITH TROPONIN T: A COMPARATIVE STUDY OF SKELETAL AND CARDIAC MUSCLE TROPONINS
}

\author{
Kazuhiko Yamamoto ${ }^{1}$, Kiyohide Nunol $^{2}$ and Masatoshi Fujishima ${ }^{2}$ \\ ${ }^{1}$ Health Services Center, Kyushu Institute of Design, Shiobaru, Minamiku, Fukuoka 815, and ${ }^{2}$ Second \\ Department of Internal Medicine, Faculty of Medicine, Kyushu University, Fukuoka 812, Japan
}

\begin{abstract}
1) We investigated the interactions between troponin $C$ and troponin $T$, and between calmodulin and troponin $\mathrm{T}$, in the presence of $\mathrm{Ca}^{2+}$ and $\mathrm{Sr}^{2+}$. Polyacrylamidegel electrophoresis under non-denaturing conditions and ultracentrifugation methods was used to examine the interactions. Calmodulin and skeletal troponin $\mathrm{C}$ bound to skeletal troponin $\mathrm{T}$ only in the presence of bivalent cations, whereas calmodulin and cardiac troponin $\mathrm{C}$ bound to cardiac troponin $\mathrm{T}$ in both the presence and absence of bivalent cations. 2) Skeletal troponin $\mathrm{C}$ bound to the skeletal troponin T-tropomyosin-actin complex only in the presence of bivalent cations, although cardiac troponin $\mathrm{C}$ hardly bound to the cardiac troponin T-tropomyosin-actin complex even in the presence of bivalent cations. 3) Calmodulin bound to the skeletal and cardiac troponin T-tropomyosin-actin complexes only in "the presence of bivalent cations. 4) Trifluoperazine, a calmodulin antagonist, inhibited the bivalentcation-dependent interaction between calmodulin and skeletal troponin T. 5) The results suggest that the conformation of cardiac troponin $T$ coupled with the tropomyosin-actin complex differs considerably from that of troponin $\mathrm{T}$ alone, and that the interaction between troponin $\mathrm{C}$ and troponin $\mathrm{T}$ does not play a major role in the troponin regulation of muscle contraction. The bivalent-cation-induced exposure of the hydrophobic region may enable calmodulin to bind to skeletal troponin $\mathrm{T}$.
\end{abstract}

The contraction-relaxation cycle of striated muscles is regulated by $\mathrm{Ca}^{2+}$ through the troponin-tropomyosin system (6). Troponin which consists of three subunits, troponin C, troponin I and troponin T, locates on the thin filaments (27). The interactions between troponin $\mathrm{C}$ and troponin $\mathrm{I}$, and between troponin I and the tropomyosin-actin complex are wellknown and their significance in the troponin

Abbreviations: TNT, troponin T; TNI, troponin I; TNC, troponin C; CaM, calmodulin regulation of muscle contraction is well established $(18,20)$. A number of workers have investigated the interaction between troponin $\mathrm{C}$ and troponin $\mathrm{T}(7,9,10,13,15,19,22,26)$. However, it is not clear what role the interaction between troponin $\mathrm{C}$ and troponin $\mathrm{T}$ plays in the troponin regulation (5). In the present study, we investigated the interaction between troponin $\mathrm{C}$ and troponin $\mathrm{T}$ and performed a comparative study of skeletal and cardiacmuscle troponin in an attempt to provide information about the role of troponin C-troponin $\mathrm{T}$ interaction. 


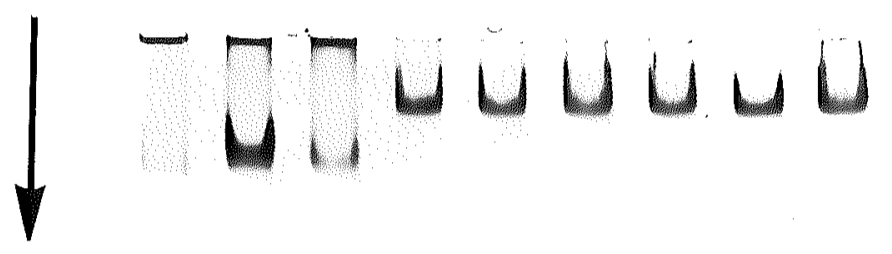

\section{$a b c d$ e f g h i}

Fig. 1 Electrophoretic pattern of the mixture of troponin $\mathrm{C}$ and troponin $\mathrm{T}$ in the presence of bivalent cations under non-denaturing conditions. A mixture of troponin $\mathrm{C}$ and troponin $\mathrm{T}$ in a $1.5: 1$ molar ratio (approximately $10 \mu \mathrm{g}$ ) was applied to a $7 \%$ polyacrylamide-gel in $25 \mathrm{mM}$ Tris $/ 240 \mathrm{mM}$ glycine buffer, $\mathrm{pH} 8.5$, containing: lanes a, $\mathrm{d}$ and g, 2 mM EGTA; lanes b, e and h, $2 \mathrm{mM} \mathrm{CaCl}_{2}$; lanes c, f and i, $2 \mathrm{mM}$ EGTA and $10 \mathrm{mM} \mathrm{SrCl}_{2}$. Lanes $\mathrm{a}, \mathrm{b}$ and $\mathrm{c}$; skeletal troponin $\mathrm{C}$ and skeletal troponin $\mathrm{T}$; lanes $\mathrm{d}$, e and $\mathrm{f}$, cardiac troponin $\mathrm{C}$ and cardiac troponin $\mathrm{T}$; lanes $\mathrm{g}, \mathrm{h}$ and $\mathrm{i}$, skeletal troponin $\mathrm{C}$ and cardiac troponin $\mathrm{T}$

Calmodulin, one of $\mathrm{Ca}^{2+}$-binding proteins, has been reported to be able to replace troponin $C$ in the regulation of muscle contraction in vitro $(1,29)$. We showed that the mode of the calmodulin regulation was considerably different from that of the troponin regulation $(29,30)$. In the present study, we investigated the interaction between calmodulin and troponin $\mathrm{T}$ and compared it with the results of troponin $\mathrm{C}$ and troponin $\mathrm{T}$ to obtain further knowledge about troponin $\mathrm{T}$.

\section{MATERIALS AND METHODS}

\section{Materials}

Trifluoperazine was purchased from Yoshitomi Chemical (Osaka, Japan). All other chemicals were of reagent grade.

\section{Preparation of Proteins}

Skeletal troponin was prepared from rabbit skeletal muscle by the method of Ebashi et al. (8) and cardiac troponin was from porcine cardiac muscle by the method of Tsukui and
Ebashi (25). Troponin was fractionated into components by the method of Perry and Cole (21). Calmodulin was prepared from bovine brain by the method of Yazawa et al. (33). Tropomyosin was prepared from rabbit skeletal muscle as described previously (31). Actin was prepared from acetone-dried powder of rabbit skeletal muscle by the method of Spudich and Watt (23).

\section{Ultracentrifugation Study}

Troponin components, calmodulin, tropomyosin and actin were mixed in a final volume of $3 \mathrm{ml}$ of solution containing $50 \mathrm{mM}$ Tris/ $\mathrm{HCl}, \mathrm{pH} 7.4$ at $4^{\circ} \mathrm{C}, 2 \mathrm{mM} \mathrm{MgCl}_{2}, 100 \mathrm{mM} \mathrm{KCl}$ and $1 \mathrm{mM}$ EGTA or $1 \mathrm{mM} \mathrm{CaCl}$ or $1 \mathrm{mM}$ EGTA and $2 \mathrm{mM} \mathrm{SrCl}_{2}$. Ultracentrifugation was carried out at $100,000 \mathrm{~g}$ for $2 \mathrm{~h}$ at $4^{\circ} \mathrm{C}$. After centrifugation, $0.2 \mathrm{ml}$ of a solution containing $10 \mathrm{mM}$ sodium phosphate buffer, $\mathrm{pH}$ $7.0,1 \%(\mathrm{w} / \mathrm{v})$ sodium dodecyl sulfate (SDS), $1 \%(\mathrm{v} / \mathrm{v}) 2-$ mercaptoethanol, $50 \%(\mathrm{v} / \mathrm{v})$ glycerol and $0.05 \%(\mathrm{w} / \mathrm{v})$ Bromophenol Blue was added to the pellet, which was redissolved vi- 
(a)

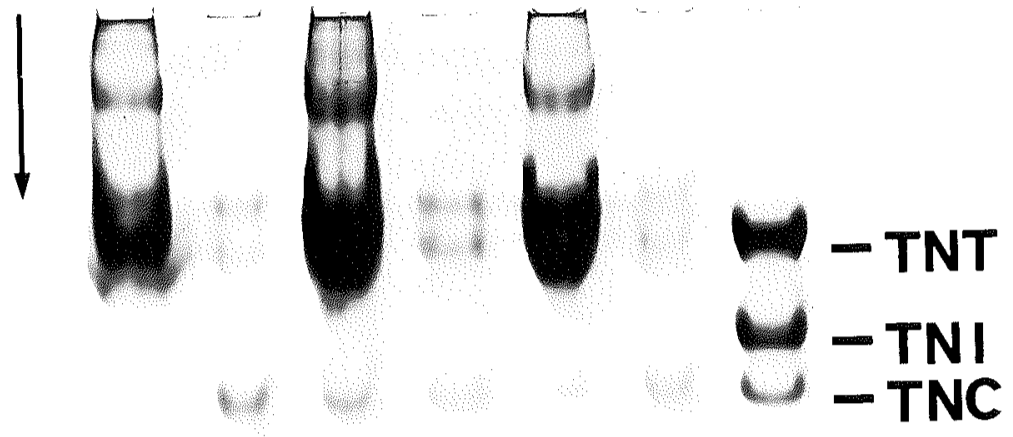

$\begin{array}{lllllll}a & b & c & d & e & f & g\end{array}$

(b)
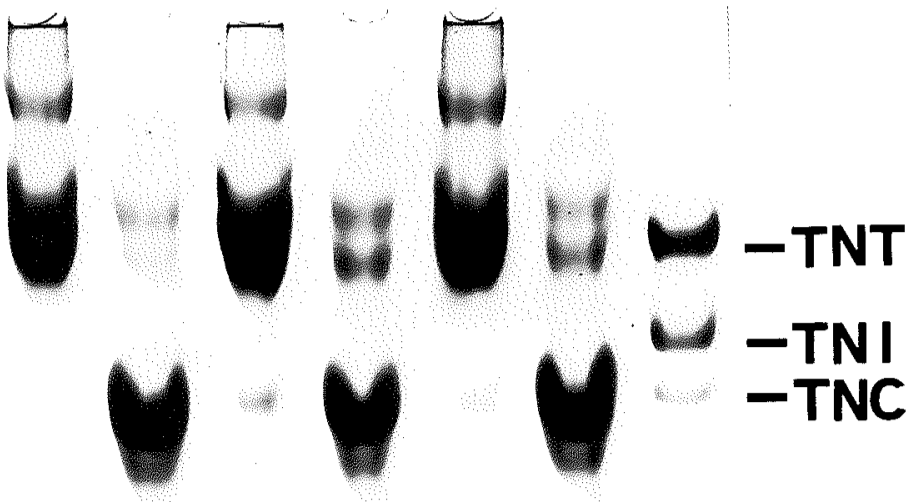

$\begin{array}{lllllll}a & b & c & d & e & f & g\end{array}$

Fig. 2 Interaction of skeletal troponin $\mathrm{C}$ with the skeletal troponin T-tropomyosin-actin complex. Proteins were mixed in a solution containing $50 \mathrm{mM}$ Tris/ $\mathrm{HCl}$ buffer, pH 7.4, $2 \mathrm{mM} \mathrm{MgCl}_{2}, 100 \mathrm{mM} \mathrm{KCl}$ and $1 \mathrm{mM}$ EGTA (lanes a and b), $1 \mathrm{mM} \mathrm{CaCl}_{2}$ (lanes $\mathrm{c}$ and d), or $1 \mathrm{mM} \mathrm{EGTA}$ and $2 \mathrm{mM} \mathrm{SrCl}_{2}$ (lanes e and $\mathrm{f}$ ). Protein concentrations in (a): actin, $0.51 \mathrm{mg} / \mathrm{ml}$; tropomyosin, $0.14 \mathrm{mg} / \mathrm{ml}$; troponin $\mathrm{T}, 0.08 \mathrm{mg} / \mathrm{ml}$; and troponin $\mathrm{C}, 0.06 \mathrm{mg} / \mathrm{ml}$. Protein concentrations in (b): actin, $0.45 \mathrm{mg} / \mathrm{ml}$; tropomyosin, $0.12 \mathrm{mg} / \mathrm{ml}$; troponin $\mathrm{T}, 0.08 \mathrm{mg} / \mathrm{ml}$; and troponin $\mathrm{C}, 0.37 \mathrm{mg} / \mathrm{ml}$. Ultracentrifugation was carried out at $100,000 \mathrm{~g}$ for $2 \mathrm{~h}$ at $4^{\circ} \mathrm{C}$. The pellet and supernatant were treated for $9 \%$ SDS-polyacrylamide-gel electrophoresis in $0.1 \mathrm{M}$ sodium phosphate buffer, pH 7.0. Lanes a, c and e, pellets; lanes b, d and f, supernatants; and lane g, skeletal troponin $\mathrm{T}, \mathrm{I}$ and $\mathrm{C}$ 
(a)

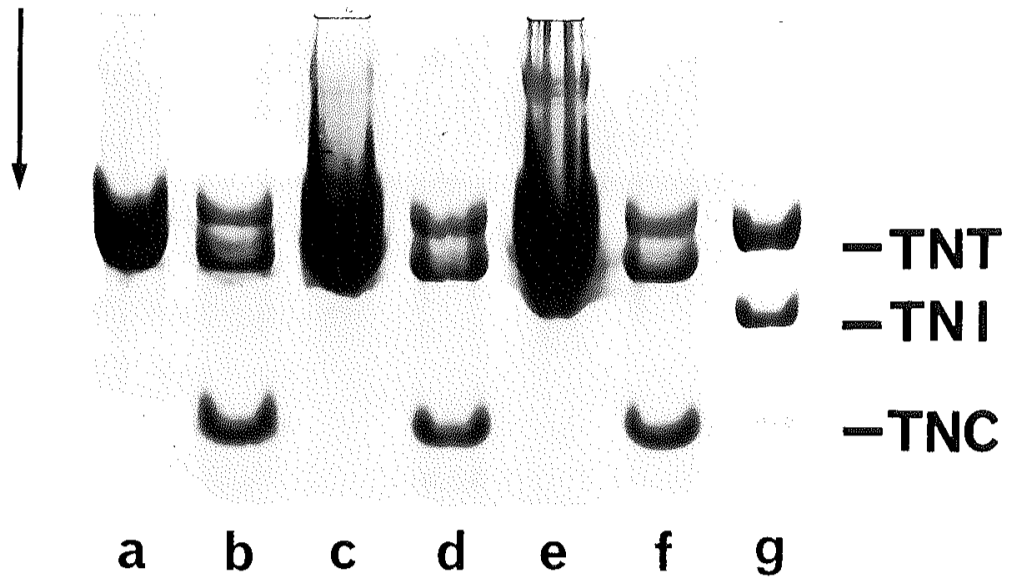

(b)

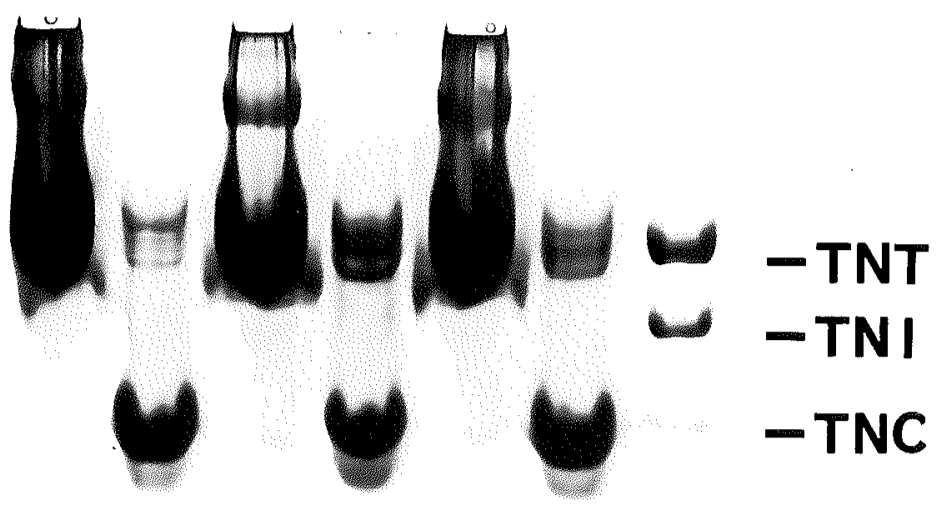

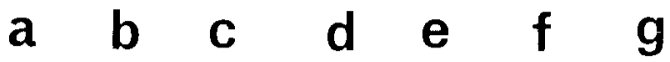

Fig. 3 Interaction of cardiac troponin $\mathrm{C}$ with the cardiac troponin T-tropomyosin-actin complex. Actin and tropomyosin were from rabbit skeletal muscle. Proteins were mixed in a solution containing $50 \mathrm{mM}$ Tris/ $\mathrm{HCl}$ buffer, $\mathrm{pH} 7.4,2 \mathrm{mM} \mathrm{MgCl} 2,100 \mathrm{mM} \mathrm{KCl}$ and $1 \mathrm{mM}$ EGTA (lanes a and b), $1 \mathrm{mM}$ $\mathrm{CaCl}_{2}$ (lanes $\mathrm{c}$ and d) or $1 \mathrm{mM} \mathrm{EGTA}$ and $2 \mathrm{mM} \mathrm{SrCl}_{2}$ (lanes e and f). Ultracentrifugation and electrophoresis were carried out as in Fig. 2. Protein concentrations in (a): actin, $0.63 \mathrm{mg} / \mathrm{ml}$; tropomyosin, $0.17 \mathrm{mg} / \mathrm{ml}$; troponin $\mathrm{T}$, $0.09 \mathrm{mg} / \mathrm{ml}$; and troponin $\mathrm{C}, 0.05 \mathrm{mg} / \mathrm{ml}$. Protein concentrations in (b): actin, $0.39 \mathrm{mg} / \mathrm{ml}$; tropomyosin, $0.12 \mathrm{mg} / \mathrm{ml}$; troponin $\mathrm{T}, 0.05 \mathrm{mg} / \mathrm{ml}$; and troponin $\mathrm{C}, 0.23 \mathrm{mg} / \mathrm{ml}$. Lanes a, $\mathrm{c}$ and $\mathrm{e}$, pellets; lanes $\mathrm{b}, \mathrm{d}$ and $\mathrm{f}$, supernatants; and lane $\mathrm{g}$, cardiac troponin $\mathrm{T}, \mathrm{I}$ and $\mathrm{C}$ 


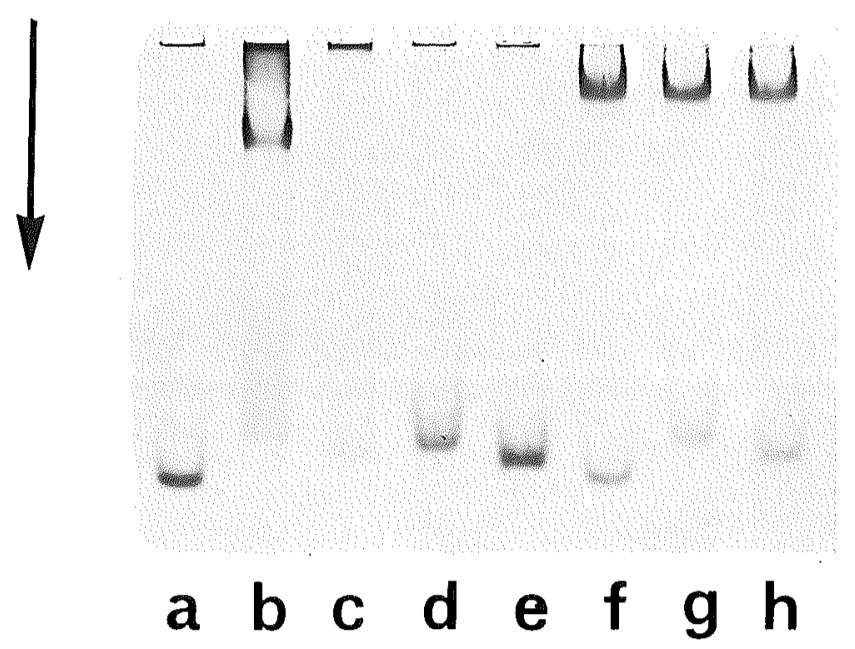

Fig. 4 Electrophoretic pattern of the mixture of calmodulin and troponin $\mathrm{T}$ in the presence of bivalent cations under non-denaturing conditions. A mixture of calmodulin and troponin $\mathrm{T}$ in a $1.5: 1$ molar ratio (approximately $10 \mu \mathrm{g}$ ) was applied to a $7 \%$ polyacrylamide-gel in $25 \mathrm{mM}$ Tris $/ 240 \mathrm{mM}$ glycine buffer, $\mathrm{pH} 8.5$, containing: lanes a and f, $2 \mathrm{mM}$ EGTA; lanes b and $\mathrm{g}, 2 \mathrm{mM}$ $\mathrm{CaCl}_{2}$; lanes $\mathrm{c}$ and $\mathrm{h}, 2 \mathrm{mM}$ EGTA and $10 \mathrm{mM} \mathrm{SrCl}_{2}$; lane d, $2 \mathrm{mM} \mathrm{CaCl}$ and $100 \mu \mathrm{M}$ trifluoperazine; and lane e, $2 \mathrm{mM}$ EGTA, $10 \mathrm{mM} \mathrm{SrCl}_{2}$ and $100 \mu \mathrm{M}$ trifluoperazine. Lanes a, b, c, d and $e$, calmodulin and skeletal troponin $T$; and lanes $f, g$ and $h$, calmodulin and cardiac troponin $\mathrm{T}$

gorously. A $5 \mathrm{ml}$ volume of $10 \%(\mathrm{w} / \mathrm{v})$ trichloroacetic acid was added to the supernatant, which was centrifuged at $2,000 \mathrm{~g}$ for $5 \mathrm{~min}$. To the precipitate was added $0.2 \mathrm{ml}$ of the $1 \%$ SDS solution described above.

\section{Polyacrylamide-Gel Electrophoresis}

SDS-polyacrylamide-gel electrophoresis was performed in $100 \mathrm{mM}$ sodium phophate buffer, pH 7.0, as described by Weber and Osborn (28). The sample solution $(15-20 \mu 1)$ was applied to a $9 \%$ polyacrylamide slab-gel. Trisglycine gel electrophoresis was carried out on a $7 \%$ polyacrylamide-gel as described previously (30). The protein concentration was determined as described previously (29).

\section{RESULTS}

Electrophoretic Study on the Interaction of Troponin $C$ with Troponin $T$ under Nondenaturing Conditions

Skeletal troponin $\mathrm{C}$ formed a complex with skeletal troponin $\mathrm{T}$ in the presence of $\mathrm{Ca}^{2+}$ (Fig. 1, lane b) and $\mathrm{Sr}^{2+}$ (Fig. 1, lane c), but not in the absence of bivalent cations (Fig. 1, lane a). Trifluoperazine did not inhibit the bivalent-cation-dependent interaction between skeletal troponin $\mathrm{C}$ and troponin $\mathrm{T}$ (data not shown). Cardiac troponin $\mathrm{C}$ formed a complex with cardiac troponin $\mathrm{T}$ in both the presence and absence of bivalent cations (Fig. 1, lanes d, e and f). Skeletal troponin C formed a complex with cardiac troponin $\mathrm{T}$ regardless of the concentrations of bivalent cations (Fig. 1, lanes $\mathrm{g}, \mathrm{h}$ and $\mathrm{i}$ ).

\section{Inrteraction of Skeletal Troponin $C$ with the Skeletal Troponin T-Tropomyosin-Actin Complex}

Skeletal troponin $\mathrm{C}$ bound to the troponin $\mathrm{T}$ tropomyosin-actin complex in the presence of $\mathrm{Ca}^{2+}$ (Fig. 2a, lanes c and d) and $\mathrm{Sr}^{2+}$ (Fig. 2a, lanes e and $f$ ), but not in the absence of bivalent cations (Fig. 2a, lanes a and b). When a large amount of troponin $\mathrm{C}$ was added, tropo- 


\section{(a)}

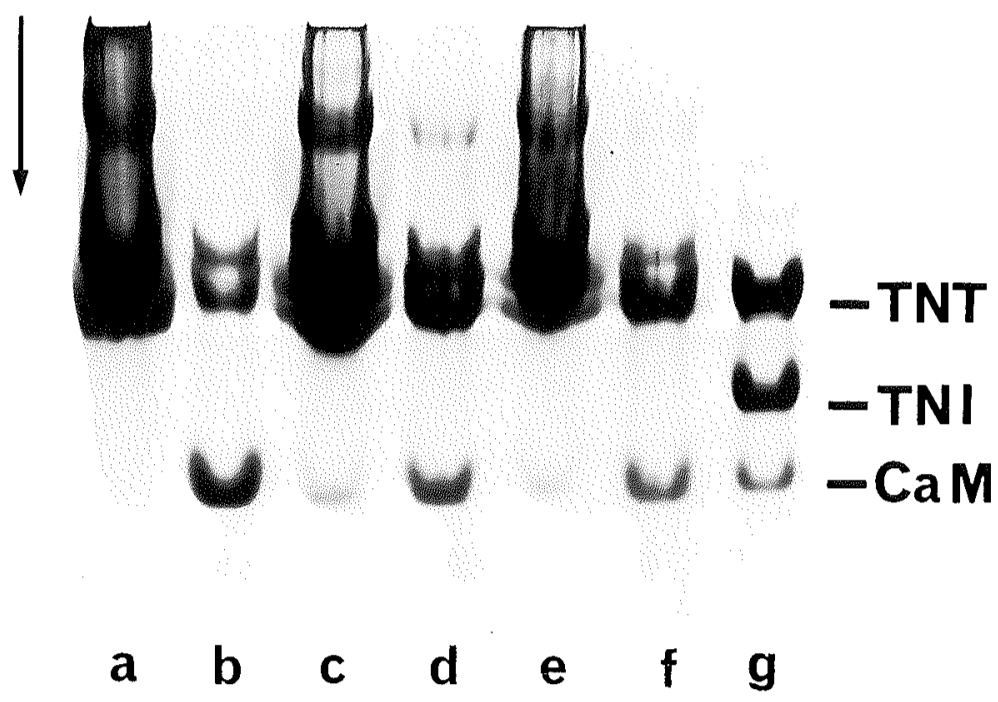

(b)
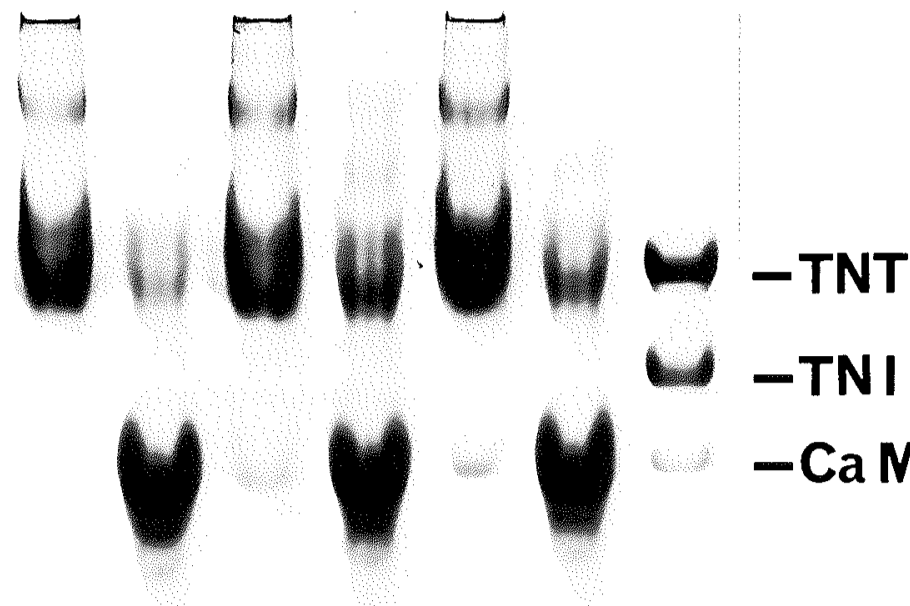

$-\mathrm{Ca} M$

\section{$\begin{array}{lllllll}a & b & c & d & e & f & g\end{array}$}

Fig. 5 Interaction of calmodulin with the skeletal troponin T-tropomyosinactin complex in the presence of bivalent cations. Proteins were mixed in a solution containing $50 \mathrm{mM}$ Tris/ $\mathrm{HCl}$ buffer, $\mathrm{pH} 7.4,2 \mathrm{mM} \mathrm{MgCl}_{2}, 100 \mathrm{mM}$ $\mathrm{KCl}$ and $1 \mathrm{mM}$ EGTA (lanes a and b), $1 \mathrm{mM} \mathrm{CaCl}_{2}$ (lanes $\mathrm{c}$ and d), or $1 \mathrm{mM}$ EGTA and $2 \mathrm{mM} \mathrm{SrCl}_{2}$ (lanes e and f). Protein concentrations in (a): actin, $0.51 \mathrm{mg} / \mathrm{ml}$; tropomyosin, $0.17 \mathrm{mg} / \mathrm{ml}$; troponin $\mathrm{T}, 0.10 \mathrm{mg} / \mathrm{ml}$; and calmodulin, $0.06 \mathrm{mg} / \mathrm{ml}$. Protein concentrations in (b): actin, $0.45 \mathrm{mg} / \mathrm{ml}$; tropomyosin, $0.12 \mathrm{mg} / \mathrm{ml}$; troponin $\mathrm{T}, 0.08 \mathrm{mg} / \mathrm{ml}$; and calmodulin, $0.37 \mathrm{mg} / \mathrm{ml}$. Ultracentrifugation and electrophoresis were carried out as in Fig. 2. Lanes a, $\mathrm{c}$ and e, pellets; lanes, b, $d$ and f, supernatants; and lane g, skeletal troponin T, I and calmodulin 
(a)

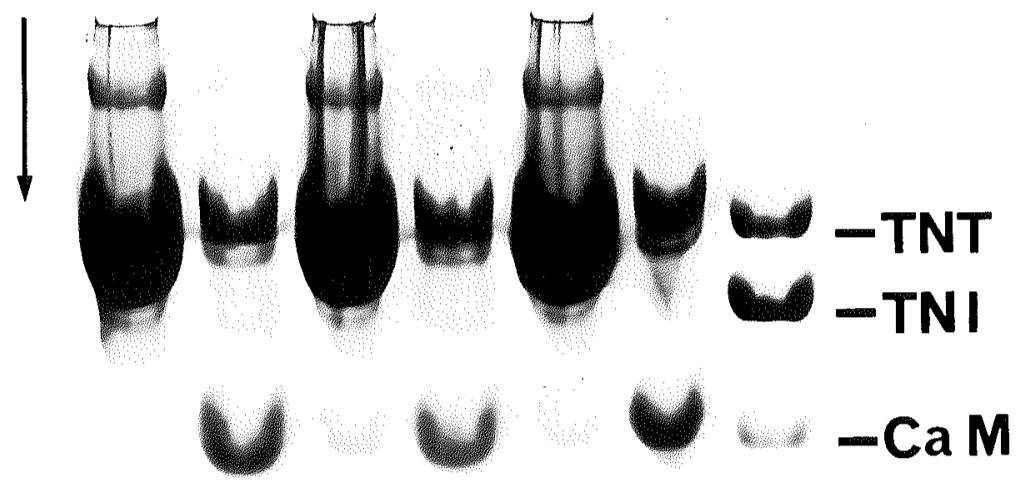

$\begin{array}{lllllll}\text { a } & \text { b } & \text { c } & \text { d } & \text { e } & f & g\end{array}$

(b)

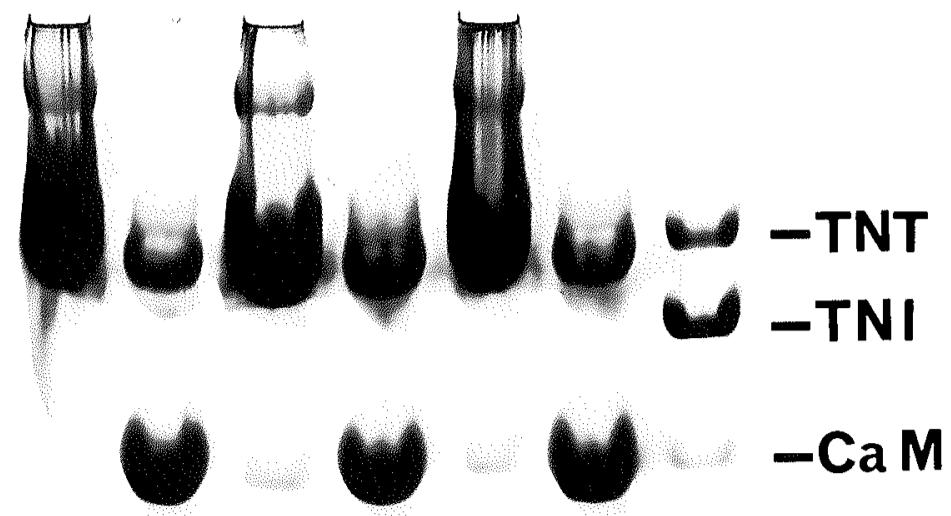

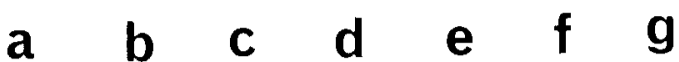

Fig. 6 Interaction of calmodulin with the cardiac troponin T-tropomyosinactin complex in the presence of bivalent cations. Actin and tropomyosin were from rabbit skeletal muscle. Proteins were mixed in a solution containing $50 \mathrm{mM}$ Tris/ $/ \mathrm{HCl}, 2 \mathrm{mM} \mathrm{MgCl}, 100 \mathrm{mM} \mathrm{KCl}$ and $1 \mathrm{mM} \mathrm{EGTA}$ (lanes a and b), $1 \mathrm{mM} \mathrm{CaCl}_{2}$ (lanes c and d), or $1 \mathrm{mM}$ EGTA and $2 \mathrm{mM} \mathrm{SrCl}_{2}$ (lanes e and f). Protein concentrations in (a): actin, $0.56 \mathrm{mg} / \mathrm{ml}$; tropomyosin, $0.15 \mathrm{mg} / \mathrm{ml}$; troponin T, $0.08 \mathrm{mg} / \mathrm{ml}$; and calmodulin, $0.04 \mathrm{mg} / \mathrm{ml}$. Protein concentrations in (b): actin, $0.49 \mathrm{mg} / \mathrm{ml}$; tropomyosin, $0.16 \mathrm{mg} / \mathrm{ml}$; troponin $\mathrm{T}, 0.07 \mathrm{mg} / \mathrm{ml}$; and calmodulin, $0.36 \mathrm{mg} / \mathrm{ml}$. Ultracentrifugation and electrophoresis were carried out as in Fig. 2. Lanes a, $c$ and e, pellets; lanes b, $d$ and f, supernatants; and lane $\mathrm{g}$, cardiac troponin $\mathrm{T}, \mathrm{I}$ and calmodulin 
nin $\mathrm{C}$ bound to troponin $\mathrm{T}$ in the presence of $\mathrm{Ca}^{2+}$ and $\mathrm{Sr}^{2+}$ (Fig. 2b, lanes $\mathrm{c}$ and e), but not in the absence of bivalent cations (Fig. 2b, lanes $a$ and $b$ ), indicating that the amount of troponin $\mathrm{C}$ added has little effect on the interaction.

Interaction of Cardiac Troponin $C$ with the Cardiac Troponin T-Tropomyosin-Actin Complex

Cardiac troponin $\mathrm{C}$ did not bind to the cardiac troponin T-tropomyosin-actin complex regardless of the concentrations of bivalent cations (Fig. 3a, lanes a, $c$ and e). When a large amount of troponin $\mathrm{C}$ was added, troponin $\mathrm{C}$ hardly bound to the troponin T-tropomyosinactin complex in both the presence and absence of bivalent cations (Fig. 3b, lanes a, c and $\mathrm{e}$ ). The result shows that the amount of cardiac troponin $\mathrm{C}$ added has little effect on the interaction.

\section{Electrophoretic Study on the Interaction of Calmodulin with Troponin $T$ under Non- denaturing Conditions}

Calmodulin formed a complex with skeletal troponin $\mathrm{T}$ in the presence of $\mathrm{Ca}^{2+}$ (Fig. 4, lane b), but not in its absence (Fig. 4, lane a). Calmodulin bound to skeletal troponin $\mathrm{T}$ but did not produce a clear band in the presence of $\mathrm{Sr}^{2+}$ (Fig. 4, lane c). Trifluoperazine inhibited the bivalent-cation-dependent interaction between calmodulin and skeletal troponin $\mathrm{T}$ (Fig. 4, lanes d and e). Calmodulin formed a complex with cardiac troponin $\mathrm{T}$ in both the presence and absence of bivalent cations (Fig. 4, lanes f, g and h). Trifluoperazine did not inhibit the bivalent-cation-independent interaction between calmodulin and cardiac troponin $\mathrm{T}$ (data not shown).

\section{Interaction of Calmodulin with the Skeletal and Cardiac Troponin T-Tropomyosin-Actin Complexes}

Calmodulin bound to the skeletal troponin Ttropomyosin-actin complex in the presence of $\mathrm{Ca}^{2+}$ (Fig. 5a, lane c) and $\mathrm{Sr}^{2+}$ (Fig. 5a, lane e), but not in the absence of bivalent cations (Fig. 5a, lane a). When a large amount of calmodulin was added, calmodulin bound to skeletal troponin $\mathrm{T}$ in the presence of bivalent cations (Fig. 5b, lanes $\mathrm{c}$ and e), but not in their absence (Fig. 5b, lane a). Calmodulin showed the same bivalent-cation-dependent interaction with cardiac troponin $T$ (Fig. 6a, lanes a, c and e) as with skeletal troponin $\mathrm{T}$. When a large amount of calmodulin was added, calmodulin bound to cardiac troponin $\mathrm{T}$ in the presence of bivalent cations (Fig. 6b, lanes $\mathrm{c}$ and e), but not in the absence of bivalent cations (Fig. 6b, lane a). The results show that the amount of calmodulin added has little effect on the interaction.

\section{DISCUSSION}

It has been shown that skeletal troponin $\mathrm{C}$ binds to skeletal troponin $\mathrm{T}$ and that the interaction between troponin $\mathrm{C}$ and troponin $\mathrm{T}$ is intensified by $\mathrm{Ca}^{2+}(7,9,13,15-17,26)$. Jackson et al. (11) showed that the complex of troponin $\mathrm{C}$ and troponin $\mathrm{T}$ was not formed in the presence of tropomyosin. Furthermore, it has been shown that troponin $\mathrm{C}$ hardly bound to troponin $\mathrm{T}$ regardless of whether $\mathrm{Ca}^{2+}$ was present or not when both troponin $\mathrm{C}$ and troponin $\mathrm{T}$ were applied to a tropomyosin-Sepharose column $(19,24)$. However, Margossian and Cohen (14) obtained the results that troponin $\mathrm{C}$ bound to the troponin $\mathrm{T}$-tropomyosin paracrystals. In the present study, we demonstrated that skeletal troponin $\mathrm{C}$ bound to skeletal troponin $\mathrm{T}$ and to the skeletal troponin $\mathrm{T}$ tropomyosin-actin complex in a bivalentcation-dependent manner.

Cardiac troponin $\mathrm{C}$ has been shown to bind to cardiac troponin $\mathrm{T}(2,4,12)$ and the interaction was strengthened by $\mathrm{Ca}^{2+}(4)$. However, Byers and Kay (3) observed no interaction between cardiac troponin $\mathrm{C}$ and troponin $\mathrm{T}$ in both the presence and absence of $\mathrm{Ca}^{2+}$ using bovine cardiac troponin. We have shown that porcine cardiac troponin $\mathrm{C}$ bound to cardiac troponin $\mathrm{T}$ regardless of the concentrations of bivalent cations (32). The present results show that both skeletal and cardiac troponin Cs bind to cardiac troponin $\mathrm{T}$ in a bivalentcation-independent manner. Unexpectedly, cardiac troponin $\mathrm{C}$ did not bind to cardiac troponin $\mathrm{T}$ coupled with the tropomyosin-actin complex. These findings suggest that the conformation of cardiac troponin $\mathrm{T}$ combined with the tropomyosin-actin complex differs 
considerably from that of troponin $T$ alone. Our present results also suggest that the interaction of troponin $\mathrm{C}$ with troponin $\mathrm{T}$ differs between skeletal and cardiac troponins. We have shown that all hybrid troponins prepared from skeletal and cardiac muscles confer $\mathrm{Ca}^{2+}$ or $\mathrm{Sr}^{2+}$ sensitivity on actomyosin ATPase (29). $\mathrm{Ca}^{2+}$ or $\mathrm{Sr}^{2+}$ sensitivity of actomyosin ATPase activity which contained skeletal troponin $\mathrm{T}$ was almost the same as that of actomyosin ATPase activity which contained cardiac troponin $\mathrm{T}(29)$. Thus $\mathrm{Ca}^{2+}$ or $\mathrm{Sr}^{2+}$ sensitivity of ATPase was hardly determined by the properties of troponin $\mathrm{T}$. These findings suggest that the interaction between troponin $\mathrm{C}$ and tropo$\operatorname{nin} \mathrm{T}$ does not play a major role in the troponin regulation of muscle contraction.

Amphlett et al. (1) showed a $\mathrm{Ca}^{2+}$-dependent interaction between calmodulin and skeletal troponin $\mathrm{T}$. Our results are in agreement with theirs in case of skeletal troponin $\mathrm{T}$ and show that the bivalent-cation-induced exposure of the hydrophobic region is important for calmodulin to bind to skeletal troponin $\mathrm{T}$. We showed a bivalent-cation-independent interaction between calmodulin and cardiac troponin $\mathrm{T}$, although calmodulin bound to cardiac troponin $\mathrm{T}$ coupled with the tropomyosin-actin complex in a bivalent-cationdependent manner. These findings indicate that the interaction between calmodulin and cardiac troponin $\mathrm{T}$ differs from that between calmodulin and cardiac troponin $\mathrm{T}$ on the thin filaments.

We express our cordial thanks to Professor I. Ohtsuki, Department of Pharmacology, Faculty of Medicine, Kyushu Unjversity, for advice and discussions.

Received for publication 7 September 1987; and in revised form 12 October 1987

\section{REFERENCES}

1. Amphlett G. W., Vanaman T. C. and Perry S. V. (1976) Effect of the troponin C-like protein from bovine brain (brain modulator protein) on the $\mathrm{Mg}^{2+}$-stimulated ATPase of skeletal muscle actomyosin. FEBS Lett. 72, 163-168

2. Burtnick L. D., McCubbin W. D. and Kay C. M. (1976) The isolation and characterization of the tropomyosin binding component (TN-T) of bovine cardiac troponin. Can. J. Biochem. 54, $546-552$
3. BYers D. M. and KAY C. M. (1982) Bovine cardiac troponin subunits: Binary complexes and reconstitution of whole troponin. FEBS Lett. 148, 12-16

4. ЕвASHI S. (1974) Interactions of troponin subunits underlying regulation of muscle contraction by Ca ion: A study on hybrid troponins. In Lipmann Symposium: Energy, Biosynthesis and Regulation in Molecular Biology (ed. RICHTER D.) Walter de Gruyter, Berlin/New York, pp. 165-178

5. Ebashi S. (1980) The Croonian Lecture, 1979: Regulation of muscle contraction. Proc. R. Soc. Lond. Ser. B 207, 259-286

6. Ebashi S. and Endo M. (1968) Calcium ion and muscle contraction. Prog. Biophys. Mol. Biol. 18, 123-183

7. Ebashi S., Ohnishi S., Abe S. and Maruyama K. (1974) A spin-label study on calciuminduced conformational changes of troponin components. J. Biochem. 75, 211-213

8. Ebashi S., Wakabayashi T. and Ebashi F. (1971) Troponin and its components. J. Biochem. 69, 441-445

9. HirchсосK S. E. (1981) Study of the structure of troponin-C by measuring the relative reactivities of lysines with acetic anhydride. J. Mol. Biol. 147, 153-173

10. Io T. (1985) Conformational change of troponin $\mathrm{T}$ induced by calcium binding to troponin C. J. Biochem. 98, 261-263

11. Jackson P., Amphlett G. W. and Perry S. V. (1975) The primary structure of troponin $T$ and the interaction with tropomyosin. Biochem. $J$. 151, 85-97

12. JaCobson A. L., Devin G. and Braun H. (1981) Thermal denaturation of beef cardiac troponin and its subunits with and without calcium ion. Biochemistry 20, 1694-1701

13. Mani R. S., McCubbin W. D. and Kay C. M. (1974) Physicochemical studies on the complexes troponin $\mathrm{C}$ with troponin $\mathrm{T}$, and reconstituted troponin, and their interaction with calcium ions. Biochemistry 13, 5003-5007

14. Margossian S. S. and Cohen C. (1973) Troponin subunit interactions. J. Mol. Biol. 81, 409413

15. Molr A. J. G., Cole H. A. and Perry S. V. (1977) The phosphorylation sites of troponin $T$ from white skeletal muscle and the effects of interaction with troponin $\mathrm{C}$ on their phosphorylation by phosphorylase kinase. Biochem. $J$. 161, 371-382

16. Ohara O., Takahashi S. and OoI T. (1980) A study on troponin-T and troponin-C interaction by cross-linking reagents. In Muscle Contraction: Its Regulatory Mechanisms (ed. EBASHI S., Maruyama K. and Endo M.) Japan Sci. Soc. 
Press, Tokyo/Springer-Verlag, Berlin, pp. 259265

17. Ohnishi S., Maruyama K. and Ebashi S. (1975) Calcium-induced conformational changes and mutual interactions of troponin components as studied by spin labeling. J. Biochem. 78, 73-81

18. Ohtsuki I., MaruYama K. and Ebashi S. (1986) Regulatory and cytoskeletal proteins of vertebrate skeletal muscle. Adv. Protein Chem. 38, 167

19. Pearlstone J. R. and Smillie L. B. (1982) Binding of troponin- $T$ fragments to several types of tropomyosin. Sensitivity to $\mathrm{Ca}^{2+}$ in the presence of troponin-C. J. Biol. Chem. 257, 1058710592

20. Perry S. V. (1979) The Twelfth CIBA Medal Lecture: The regulation of contractile activity in muscle. Biochem. Soc. Trans. 7, 593-617

21. Perrey S. V. and Cole H. A. (1974) Phosphorylation of troponin and the effects of interactions between the components of the complex. Biochem. J. 141, 733-743

22. Potter J. D. and Gergely J. (1974) Troponin, tropomyosin, and actin interactions in the $\mathrm{Ca}^{2+}$ regulation of muscle contraction. Biochemistry 13, 2697-2703

23. Spudich J. A. and Watt S. (1971) The regulation of rabbit skeletal muscle contraction. I. Biochemical studies of the interaction of the tropomyosin-troponin complex with actin and the proteolytic fragments of myosin. J. Biol. Chem. 246, 4866-4871

24. Tanokura M. and Ohtsuki I. (1984) Interactions among chymotryptic troponin T subfragments, tropomyosin, troponin I and troponin
C. J. Biochem. 95, 1417-1421

25. Tsukui R. and Ebashi S. (1973) Cardiac troponin. J. Biochem. 73, 1119-1121

26. VAN EeRD J.-P. and KaWASAKI Y. (1973) Effect of calcium (II) on the interaction between the subunits of troponin and tropomyosin. Biochemistry 12, 4972-4980

27. Weber A. and Murray J. M. (1973) Molecular control mechanisms in muscle contraction. Physiol. Rev. 53, 612-673

28. WEBer K. and OsBorn M. (1969) The reliability of molecular weight determinations by dodecyl sulfate-polyacrylamide gel electrophoresis. $J$. Biol. Chem. 244, 4406-4412

29. Yамамото K. (1983) Sensitivity of actomyosin ATPase to calcium and strontium ions. Effect of hybrid troponins. J. Biochem. 93, 1061-1069

30. Yamamoto K., Nakayama H., Nunol K. and FUJishima M. (1987) Interaction of calmodulin with troponin I and the troponin-tropomyosinactin complex. Effect of $\mathrm{Ca}^{2+}$ and $\mathrm{Sr}^{2+}$ ions. Biochem. J. 241, 905-909

31. Yamamoto K. and Ohtsuki I. (1982) Effect of phosphorylation of porcine cardiac troponin I by $3^{\prime}: 5^{\prime}$-cyclic AMP-dependent protein kinase on the actomyosin ATPase activity. J. Biochem. 91, 1669-1677

32. Үамамото K. and OhtsuKi I. (1985) Interaction of troponin $\mathrm{C}$ and calmodulin with tropo$\operatorname{nin} I$ and troponin T. An electrophoretic study. Fukuoka Igaku Zasshi 76, 85-89

33. Yazawa M., Sakuma M. and Yagi K. (1980) Calmodulins from muscles of marine invertebrates, scallop and sea anemone. J. Biochem. 87, 1313-1320 